\title{
Rayleigh Convection in a Fluid Heated Differentially at the Bottom
}

\section{Part I: Experimental Study}

\author{
By Yasumasa Ookouchi, Saburo Miyahara and Ryukichi Sawada \\ Department of Physics, Kyushu University, Fukuoka \\ (Manuscript received 9 May 1977, in revised form 22 June 1977)
}

\begin{abstract}
Roll type Rayleigh convection with a linear temperature distribution along the bottom is experimentally investigated with silicone oil.

Results are: a) Convection due to the horizontal temperature gradient is an asymmetric single circulation. b) Rayleigh convection is deformed by the differential heating so that large direct convection cells (whose sense of rotation is same with that driven by the differential heating) and small indirect convection cells stand alternately. c) When stable and unstable regions exist side by side, a single convection due to the horizontal temperature gradient develops in the stable region, while deformed Rayleigh convections develop in the unstable region. d) As the horizental gradient increases, the wave length of the Rayleigh convection tends to increase to converge to a certain value.
\end{abstract}

\section{Introduction}

The Rayleigh convection is essentially due to the vertical temperature gradient. However, when we apply the theory to atmospheric phenomena, we have to take the horizontal temperature gradient also. Because the convection may be modified significantly by horizontal differential heating. In order to find the effect experimentally, use is made of a single row cellular convection which develops in a long transparent convection chamber filled with silicone oil and heated from below differentially with a constant gradient. A similar experiment with non-conductive top was performed by Rossby (1965), but without control of the vertical stratification. In the present study, the top is kept at a constant temperature to control the vertical stratification. The differential heating reinforces cells with direct sense of rotation (direct with regard to the gradient of the differential heating), while indirect cells are suppressed. Some characteristic features of the deformed cells are observed.

\section{Experimental apparatus}

The present convection chamber is $40 \mathrm{~cm}$ in length, $2 \mathrm{~cm}$ in breadth and $4 \mathrm{~cm}$ in depth. Its side walls are made of transparent double layered acrylic resin of $0.2 \mathrm{~cm}$ in thickness so that not

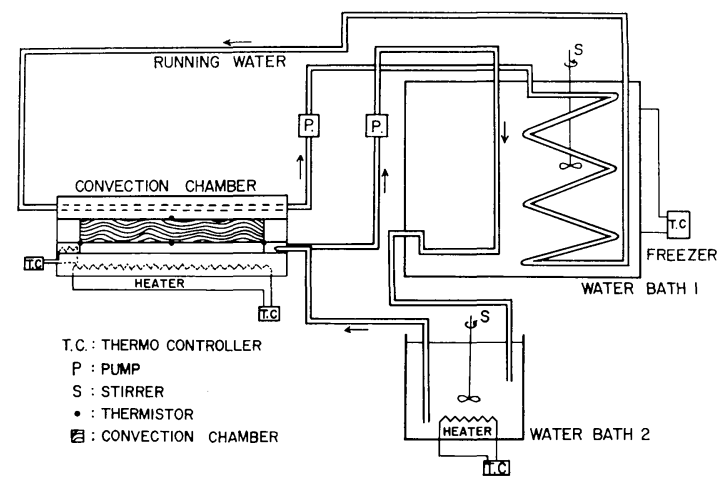

Fig. 1 Schematic diagram of the apparatus.

only convection cells may be observed from outside (Ukaji \& Sawada, 1969), but also the effect of heat conduction through the side walls are more or less prevented. The expected convection cell is of a roll type. The ceiling of the chamber is made of a copper plate of some $0.8 \mathrm{~cm}$ in thickness, over which is a flat copper pipe for running water, by which the ceiling may be kept at a predetermined temperature of $10-40^{\circ} \mathrm{C}$. The bottom of the chamber is made of a copper plate of $1.0 \mathrm{~cm}$ in thickness, each end of which may be kept at a predetermined different temperature of $10-40^{\circ} \mathrm{C}$ so that the temperature of the bottom surface varies linearly along the length (Figs. 1 


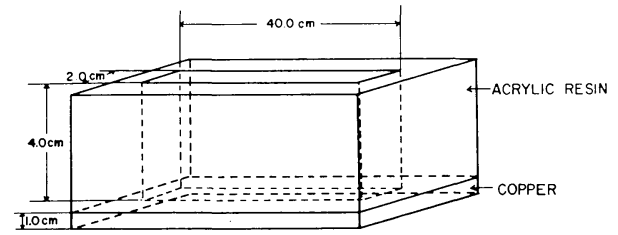

Fig. 2 Convection chamber.

Table 1. The temperature dependency of kinematic viscosity of the silicone oil.

\begin{tabular}{lcc} 
& $600 \mathrm{cSt}$ & $1000 \mathrm{cSt}$ \\
$15^{\circ} \mathrm{C}$ & 710 & 1100 \\
20 & 650 & 1000 \\
25 & 600 & 910 \\
30 & 550 & 830 \\
35 & 510 & 750 \\
\hline
\end{tabular}

and 2). The accuracy of temperature control of the top and bottom surfaces is $\pm 0.01^{\circ} \mathrm{C}$. When, however, the experiment takes a long time waiting for steady state convective motions, the effect of room temperature change becomes so large that the accuracy drops down to some $\pm 0.1^{\circ} \mathrm{C}$. The chamber is filled with silicone oil, the viscosity of which is either about $1000 \mathrm{cSt}$ or about 600 cSt. Although the viscosity varies with temperature as shown in Table 1 , we will call them 1000 cSt or $600 \mathrm{cSt}$ silicone oil for the sake of simplicity.

\section{Critical Rayleigh number}

Before investigating the effect of differential heating, one needs to find the critical Rayleigh number $R_{v c}$ for the present apparatus. The experiment for the determination was conducted for the silicone oil with viscosity of $600 \mathrm{cSt}$. The experiment was performed by increasing stepwise the temperature difference between the top and the bottom surfaces. Each step needed to be continued for up to some $4 \mathrm{hrs}$ in order to confirm that no convective motion starts to develop. After each confirmation, the temperature of the bottom surface was increased by an amount of $0.2^{\circ} \mathrm{C}$, while that of the top was unchanged. In this way, the critical Rayleigh number was found to be $1.9 \times 10^{4} \pm 0.2 \times 10^{4}$. The physical constants of the silicone oil used for calculating Rayleigh number are shown in Table 2. Theoretical investigation (Pellow \& Southwell, 1940) suggests a value of $1.7 \times 10^{3}$ for the so-called rigid-rigid boundary case, which corresponds to the present case, about 10 times smaller than the present finding. This discrepancy between the theory and
Table 2. Physical constants of silicone oil (Toshiba Co.)

$\begin{array}{ll}\text { thermometric conductivity } & 1.06 \times 10^{-3} \mathrm{~cm}^{2} / \mathrm{sec} \\ \text { coefficient of volume expansion } & 9.20 \times 10^{-4} / \mathrm{deg} \\ \text { specific heat } & 0.36 \mathrm{cal} / \mathrm{g} \\ \text { mean density } & 0.972 \mathrm{~g} / \mathrm{cm}^{3}\end{array}$

our experiment is partly due to a fact that, while our chamber has lateral walls, the theoretical model extends to infinite and assumes no lateral walls. The side walls of the chamber not only conduct heat, but also absorb momentum, so that the onset of convective motions may be suppressed considerably. The wall effect has been formulated for a free-free boundary case (Ukaji \& Matsuno, 1970, Kondo, 1971), which, however, gives a value of $3.4 \times 10^{3}$, still much smaller than the present finding. For the present experiment, not only rigid-rigid boundary conditions but also side wall effects must be taken into account. It is quite understandable that $R_{v c}$ is much larger.

As Ukaji and Sawada (1969) have shown experimentally, the number of cells are not sensitively depending on Rayleigh number $R_{v}$. It is whether $\boldsymbol{R}_{v}$ is larger than $\boldsymbol{R}_{v c}$ or not that matters. In the present study of the case of the unstable stratification, $R_{v}$ varies from $R_{v c}$ to $6 \cdot R_{v c}$.

\section{Deformed Rayleigh convection}

By keeping each end of the bottom copper plate at a constant (but different to each other) temperature, one obtains a steady, almost linear temperature distribution along the bottom surface (Fig. 3). The Rayleigh number varies also almost linearly along the length of the chamber. Let us

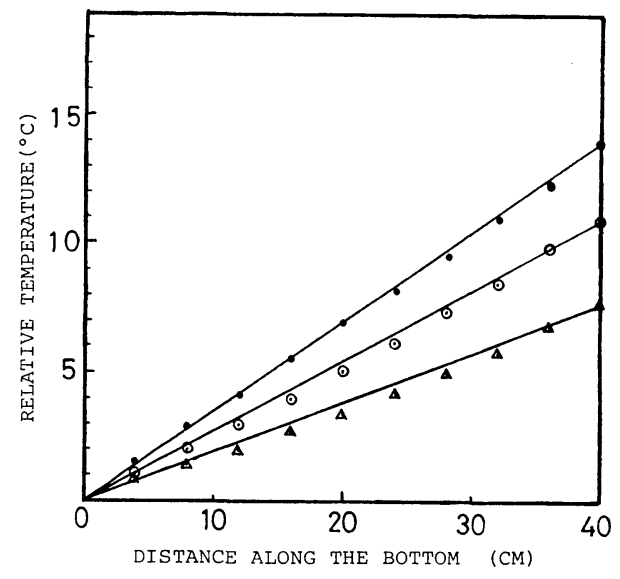

Fig. 3 Quasi-linearity of the steady bottom temperature distribution. 

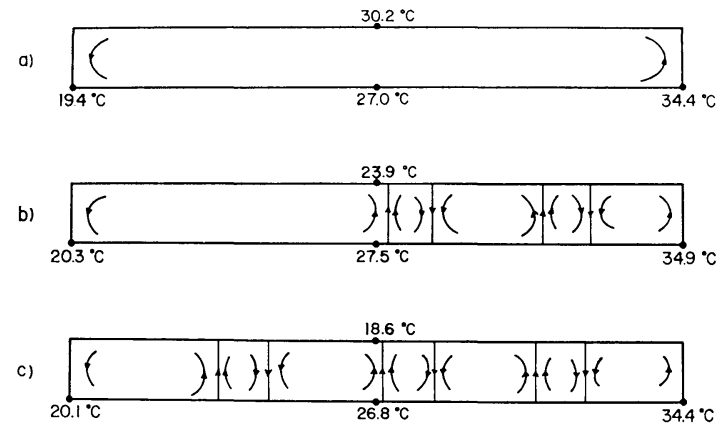

Fig. 4 Stream patterns for three different temperature contrasts between top and bottom, horizontal temperature difference being nearly constant.

observe following three dynamically different cases:

(a) Rayleigh number is below critical throughout the chamber.

(b) Rayleigh number is above critical over a warmer region, but is below over the remaining cooler region.

(c) Rayleigh number is above critical almost throughout the chamber.

In case (a), no Rayleigh convection develops. This case is similar to what Rossby (1965) discussed and the resultant flow have same features. There develops only a single flat circulatory cell occupying whole chamber. This is due to the differential heating. The circulation is naturally direct with regard to the horizontal temperature gradient. The circulatory motion is apparently asymmetric, with its center shifted somewhat to the warmer side (see Fig. 4 a)).

In case (b), the fluid is partly unstable with supercritical Rayleigh numbers. Rayleigh convection cells develop in the unstable region in pairs, but is apparently deformed by the differential heating. Each pair consists of a large direct (with regard to the differential heating) cell and a small indirect cell. It seems that the direct cell is reinforced by the horizontal temperature gradient at the bottom, while the indirect cell is suppressed. Unless the unstable region is long enough to cover at least a pair of cells, no Rayleigh convection develops. When the region becomes long enough to cover one more pair, the number of pairs increases abruptly by one. However, the cell size seems to be independent of the length of the unstable region. In the remaining stable region, there is always a single direct weak cell due to the differential heating. (see Fig. 4 b))

As the unstable region extends further, one

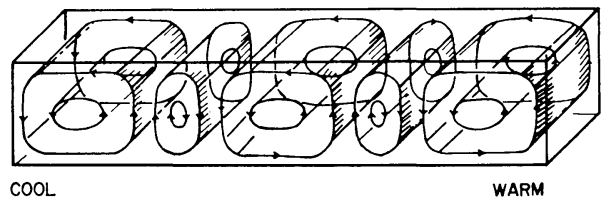

Fig. 5 Deformed Rayleigh convection in a fluid layer with almost linear horizontal bottom temperature gradient.

finally reaches case (c). The Rayleigh number, which is supercritical almost throughout the chamber, increases linearly from one end to the other. The flow pattern varies with time extremely slowly, and the confirmation of the steady state usually takes several days. Whole region is occupied by pairs of deformed Rayleigh cells, large direct cells and small indirect cells stand alternately. A weak single direct cell due to the differential heating may or may not exist in the cooler end region. (see Fig. 4 c)) Fig. 5 shows an example.

\section{Characteristics of deformed Rayleigh cell}

The most characteristic feature of the deformation of Rayleigh convection cells is the appearance of large direct cells and small indirect cells in pairs. The differential heating apparently reinforces direct cells and suppresses indirect cells. If this is the case, the ratio of sizes of both cells should increase as the temperature difference between both ends increases. Fig. 6 shows that the ratio $f$ of the width of large cell to that of small one increases linearly as the temperature difference between both ends of the bottom plate increases. This result may be formulated as follows:

$$
f=1.0+\alpha \cdot \frac{\delta T}{L}
$$

where $L$ is the length of the convection chamber, $40 \mathrm{~cm}$, while $\delta T$ is the temperature difference between both ends, constant $\alpha$ being $8 / 3 \mathrm{~cm} / \mathrm{deg}$ in this case. As mentioned previously the cell size is little affected by vertical temperature gradient so far as $R_{v}$ is not extremely large. Therefore, we used all the data obtained in the experiments $\left(R_{v}=R_{v c} \sim 6 R_{v c}\right)$ for the present and subsequent analyses. While the differential heating reinforces direct cells and suppresses indirect cells, the width of the pair tends to increase as the temperature contrast between both end increases. Fig. 7 shows the relationship. It is interesting to notice that 


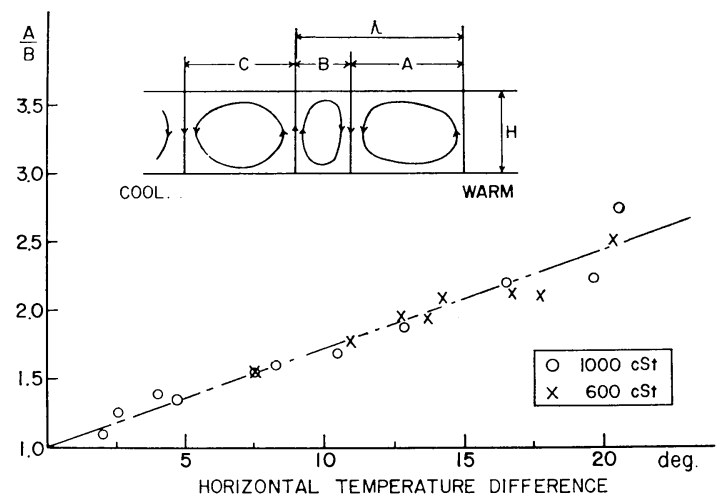

Fig. 6 Dependency on the horizontal temperature contrast of the ratio of the width of large cell, A, to that of small one, B.

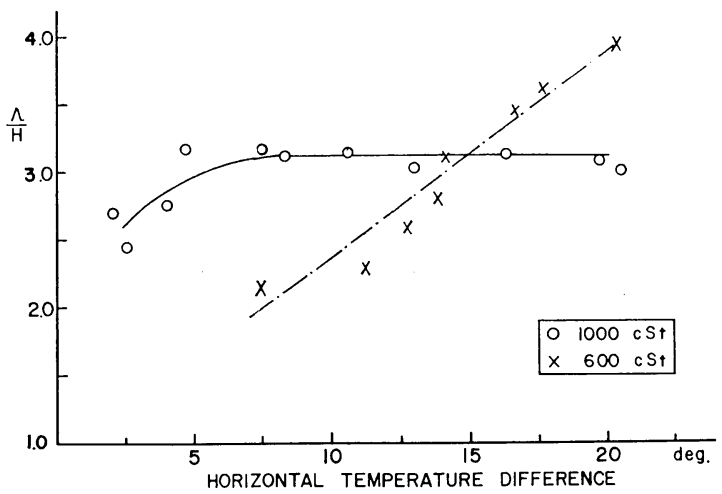

Fig. 7 Variation of the width of the pair, $\Lambda / H$, with the horizontal temperature difference.
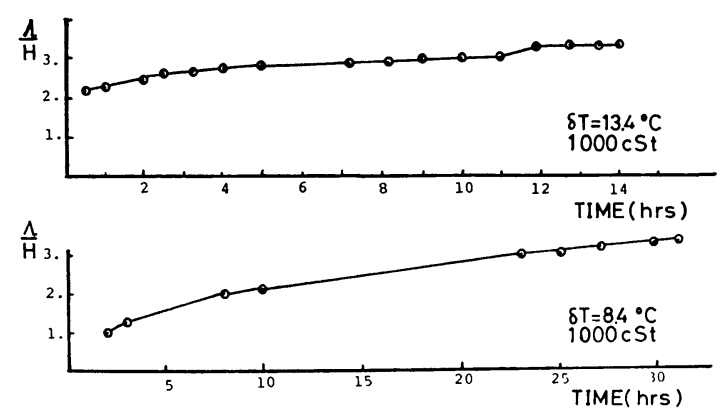

Fig. 8 Variation of the width $\Lambda / H$ with time.

the relationship is dependent upon the viscosity. In case of $1000 \mathrm{cSt}$, the width, $\Lambda=\mathrm{A}+\mathrm{B}$, seems to converge to $3 \mathrm{H}, \mathrm{H}$ being the depth. But, this tendency is not clear for the case of $600 \mathrm{cSt}$. One should compare this with Fig. 6 where no viscosity effect is seen. It is worth noting that the width as observed is not necessarily definite. As seen in Fig. 8, the width seems to continue

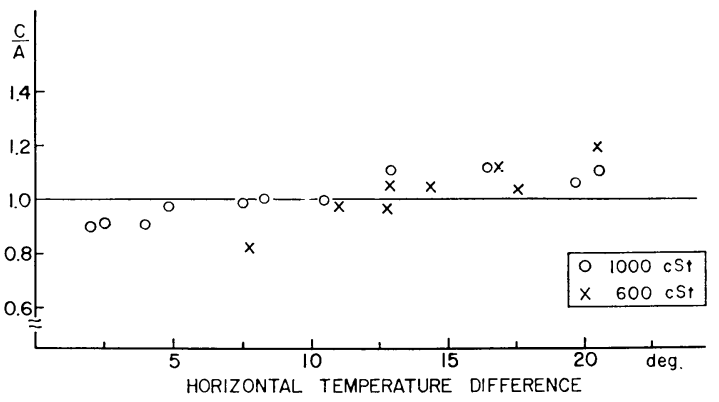

Fig. 9 Variation of the ratio of widths of two nearest direct cells, $\mathrm{C} / \mathrm{A}$, with the horizontal temperature difference.

to vary as time passes as long as the present experiment is concerned. Thus, we could not be sure if the state became steady or not even after many hours. Thus, the result presented in Fig. 7 contains a certain degree of ambiguity. Fig. 9 shows the ratio of widths of nearest two direct cells in the warmer end region seems to have a slight tendency to increase from below to above unity as the temperature difference increases.

\section{Conclusion}

The results are summarized as follows. Convection due to the horizontal temperature gradient is an asymmetric single circulation. Rayleigh convection is deformed by the differential heating so that large direct convection cells (the same sense of rotation with the differential heating) and small indirect convection cells stand alternately. The ratio of the cell width of the former to that of the latter is in proportion to the horizontal temperature gradient. When stable and unstable regions exist side by side, a single convection due to the horizontal temperature gradient develops in the stable region, while deformed Rayleigh convections develop in the unstable region. As long as the horizontal temperature gradient is kept constant, the wave length of Rayleigh convection is independent of the length of the unstable region. As the horizontal gradient increases, the wave length of the Rayleigh convection tends to increase to converge to a certain value.

\section{Acknowledgments}

The authors would like to express their sincere thanks to Prof. K. Ukaji, Fukuoka University, for his suggestions for the experiment, to Prof. M. Uryu and Messers. O. Morita and K. Kusakabe, Kyushu University, for their stimulating 
discussions. Thanks are also due to Miss Sato for her drawing figures.

\section{References}

Kondo, H., 1971: Effects of finite conductivity and finite thickness of the walls of a fluid tank on the convective instability. J. Meteor. Soc. Japan, 49, 484-493.

Ookouchi, Y., M. Uryu and R. Sawada, 1977: Rayleigh convection with differential heating. Part II: numerical study. J. Meteor. Soc. Japan, 55, 397-408.
Pellow, A., and R. V. Southwell, 1940: On maintaining convective motion in a fluid heated from below. Proc. Roy. Soc. London, A 176, 312-343.

Rossby, H. T., 1965: On thermal convection driven by non-uniform heating from below: an experimental study. Deep-Sea Res., 12, 9-16.

Ukaji, K., and R. Sawada, 1969: The convective heat transport and the number of convective cells. J. Meteor. Soc. Japan, 37, 451-456.

- and T. Matsuno, 1970: Effect of lateral walls on the onset of convective motion. $J$. Meteor. Soc. Japan, 38, 217-223.

\title{
Raileigh 型対流への非一様加熱の影響（第 1 部実験）
}

\author{
大河内 康 正・宮 原 三 郎・沢 田 龍 吉 \\ 九州大学理学部物理学教室
}

上面の温度が一定で, 底面の温度分布が一次関数の場合のロル型対流の実験を行なった。用いた液体はシリコン油 で次の样な特徵がわかった。

a) 底面の温度傾度だけによる対流は，ただ一つの非対称型循環である。

b) 底面の温度傾度により，Rayleigh 型対流は变形し，大きな直接循環（水平温度傾度による対流之同一方向の 循環）と，小さな間接循環（水平温度傾度による対流と反対方向の循環）が交互に並ぶ形になる。大小循環の幅の比 は，水平温度傾度に比例して增加する。

c）安定領域と不安定領域が共存する場合には，水平温度傾度による対流と，变形を受けた， Rayleigh 型対流が 共存する。水平温度傾度が一定である限り, Rayleigh 型対流のセルの幅は, 不安定領域の長さには依らない。

d) 水平温度傾度が增すにつれて， Rayleigh 型対流セルの幅が長くなり，さらに一定に近づく傾向が見られる。 